\title{
Taxonomic characterization of a brackish water, bloom-forming Peridiniopsis species (Peridiniales, Dinophyceae) from Iraq
}

\author{
Hameed A. Hameed ${ }^{1}$, Maria Saburova ${ }^{2^{*}}$ and Nicolas Chomérat ${ }^{3}$
}

\begin{abstract}
Background: The occurrence of a small brackish water bloom-forming dinoflagellate belonging to the genus Peridiniopsis is reported for the first time from the Shatt Al-Arab River in Iraq. Based on the study of cell morphology, this taxon was attributed to the recently described Peridiniopsis minima, recorded so far only from the Jiulongjiang River, China.

Results: The description of P. minima was extended to include some previously unreported details of the thecal surface, apical pore complex, and sulcus structure using light and scanning electron microscopy. Cells of this species from Iraq were oval to rhombic in shape and slightly dorso-ventrally compressed, with distinct red eyespot and endosymbiont nucleus. Cells were covered by a thin theca with the Kofoidian plate formula Po, X, 3', 1a, 6", 5c, $5 \mathrm{~s}, 5 \mathrm{\prime \prime \prime}, 2$ '"'. Complementing the original description of the species, five plates were discerned in the composition of the sulcal area, and the presence of small median sulcal plate was confirmed.

Conclusion: The finding of P. minima in the waters of Shatt Al-Arab River represents a new addition to the Iraqi aquatic microflora. Our observations of this dinoflagellate in brackish waters of the Shatt Al-Arab River system extend the known range of salinity tolerance for this species.
\end{abstract}

Keywords: Dinophyceae, Dinoflagellates, Iraq, Morphology, Peridiniopsis, Shatt Al-Arab River, Taxonomy, SEM

\section{Background}

Over last decades, contributions to the knowledge of microalgal flora inhabiting fresh and brackish water ecosystems of Iraq have revealed the remarkable predominance of diatoms in the composition of phytoplankton (e.g., Huq et al. 1978; Al-Handal 1989; Maulood et al. 1993, 2013; Al-Zubaidi et al. 2006), whereas a little is known in respect of occurrence and diversity of nondiatom algae including dinoflagellates so far. However, some dinoflagellates, particularly species belonging to the genera Ceratium Schrank, Peridinium Ehrenberg, and Peridiniopsis Lemmermann, can be an important integral part of fresh and brackish water ecosystems forming extensive blooms during phytoplankton succession worldwide (e.g., Trigueros 2000; Ki and Han 2005; Mac

\footnotetext{
* Correspondence: msaburova@gmail.com

${ }^{2}$ Environment and Life Sciences Research Center, Kuwait Institute for

Scientific Research, P.O. BOX 1638, 22017 Salmiya, Kuwait

Full list of author information is available at the end of the article
}

Donagh et al. 2005; Hansen and Flaim 2007; Takano et al. 2008).

To date, the records of dinoflagellates in Iraq are scarcely documented (Kell and Saad 1975; Maulood et al. 1993, 2013; Salman et al. 2013). Meanwhile, according to the last checklist of algal flora in Iraq (Maulood et al. 2013) the occurrence of Peridiniopsis species has never been previously recorded in any Iraqi water environment.

Recently, a dense population of a previously unreported small peridinioid dinoflagellate has been detected during the phytoplankton survey of the Shatt Al-Arab River in the vicinity of Basrah city, Iraq. Based on its thecal plate pattern, this taxon was attributed to the genus Peridiniopsis. In the present paper, the general morphology and the thecal plate arrangement of this species is described using light, epifluorescence, and scanning electron microscopy. New data on the distribution of this dinoflagellate within Iraqi waters are provided. 


\section{Methods}

\section{Sampling sites}

The Shatt Al-Arab River is the result of Tigris and Euphrates rivers conjunction north of Basrah city at Qurna. The river flows southwardly through the city and enter the Arabian Gulf at Fao (Fig. 1). The total length of the river is $193 \mathrm{~km}$, the width is nearly $400 \mathrm{~m}$ at Basrah city and $1500 \mathrm{~m}$ at river inflow into the Gulf. River depth ranges from $7.5 \mathrm{~m}$ at upstream to $12.5 \mathrm{~m}$ at Fao, and is affected by diurnal tide without thermal stratification (Huq et al. 1978).

The phytoplankton survey was carried out at three sampling sites in the Shatt Al-Arab River (Fig. 1). The first sampling site is situated $30 \mathrm{~km}$ south of Qurna, whereas the second sampling site is located downstream the entrance of Hor Al-Hammar into the river. The third site represents a downstream station positioned just above the inflow of Karun River into the Shatt Al-Arab River.

\section{Sampling}

Phytoplankton samples were collected by oblique tows using plankton net with $20 \mu \mathrm{m}$ mesh size and $0.6 \mathrm{~m}$ diameter during November and December 2009 and April 2010. The samples were fixed and preserved with $4 \%$ acidic Lugol's solution. In addition, in situ measurements of environmental variables (water temperature, $\mathrm{pH}$ and salinity) were obtained from a portable multiparameter handheld meter (Multi 350i, WTW) (Table 1).

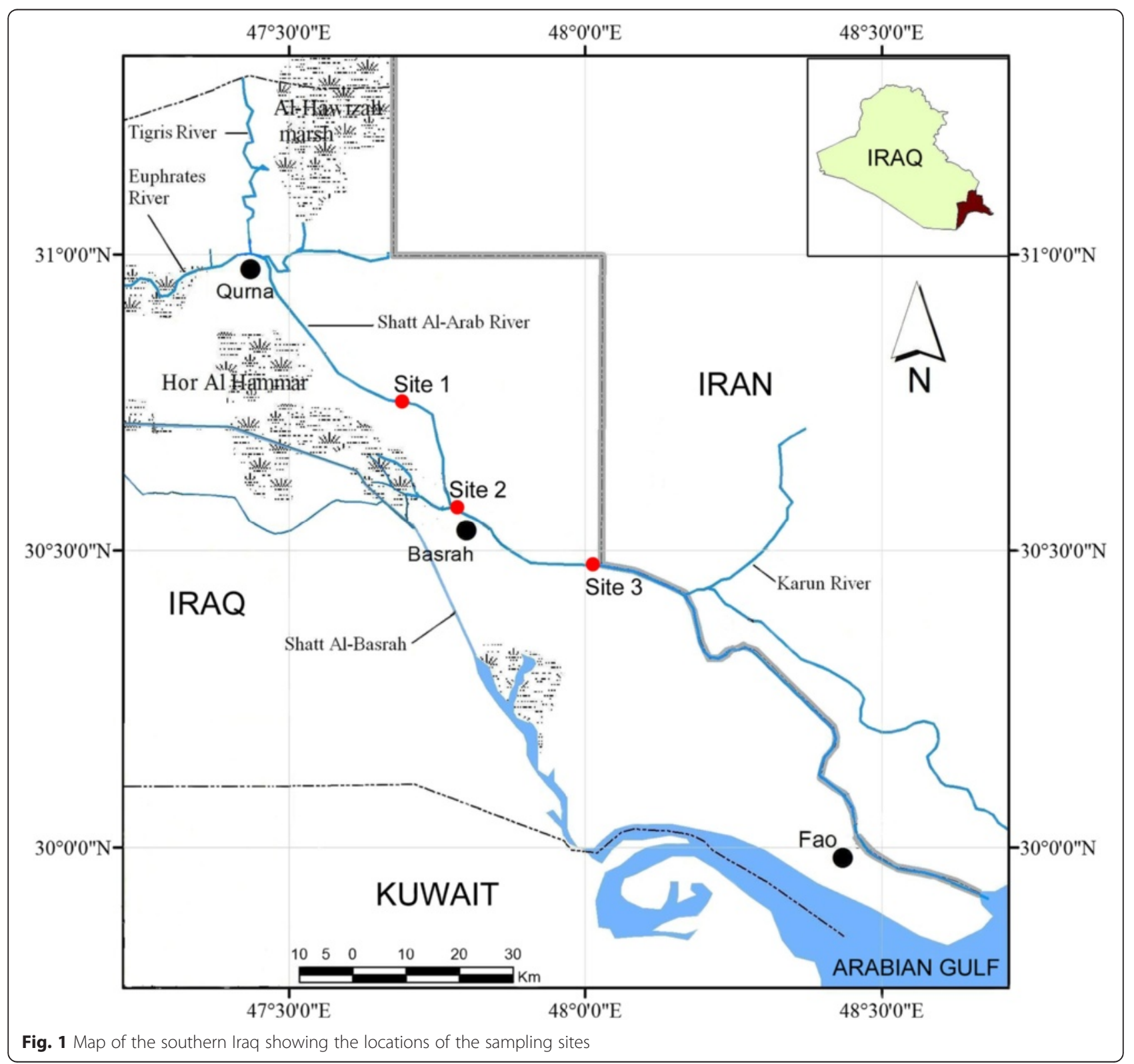


Table 1 Environmental variables at the studied sites during Peridiniopsis minima occurrence

\begin{tabular}{|c|c|c|c|c|c|}
\hline Site & Coordinates & Date & Water temperature, ${ }^{\circ} \mathrm{C}$ & $\mathrm{pH}$ & Salinity \\
\hline 1 & $\begin{array}{l}30^{\circ} 44^{\prime} 53.06^{\prime \prime} \mathrm{N} \\
47041^{\prime} 19.30^{\prime \prime} \mathrm{E}\end{array}$ & November 2009 & 23.9 & 7.99 & 2.0 \\
\hline 2 & $\begin{array}{l}30^{\circ} 34^{\prime} 34.64^{\prime \prime} \mathrm{N} \\
47046^{\prime} 27.30^{\prime \prime} \mathrm{E}\end{array}$ & December 2009 & 19.3 & 7.16 & 7.2 \\
\hline 3 & $\begin{array}{l}30^{\circ} 27^{\prime} 44.04^{\prime \prime} \mathrm{N} \\
48^{\circ} 00^{\prime} 49.80^{\prime \prime} \mathrm{E}\end{array}$ & April 2010 & 21.3 & 7.50 & 2.1 \\
\hline
\end{tabular}

\section{Samples processing}

The material was preliminary viewed alive with a Zeiss Axiophot 2 imaging microscope (Carl Zeiss AB, Göteborg, Sweden) at $400 \times$ to $1000 \times$ magnifications. For detailed observation, cells were isolated by micropipetting in preparation for high-magnification photomicroscopy. Cells were examined using a Leica DMLM microscope (Leica, Wetzlar, Germany) equipped with epifluorescence (100 W short arc mercury lamp), and Leica DFC420C digital camera at $1000 \times$ magnification. Thecal plates were observed after staining with Calcofluor White (Sigma Chemical Co.) according to the method of Fritz and Triemer (1985). To visualize nuclei, cells were stained for $30 \mathrm{~min}$ with 4',6-diamidino-2-phenylindole, dihydrochloride (DAPI, Sigma-Aldrich) fluorochrome. Scanning electron microscopy (SEM) was employed for detailed observations of the thecal surface.

For SEM, phytoplankton cells from preserved natural samples were filter mounted by a Swinnex filter-holder, rinsed twice with distilled water and subsequently dehydrated in a series of increasing ethanol concentrations $(15,30,50,70,90,95$ and $100 \%)$. The filters were critical point dried, sputter-coated with gold-palladium, and examined either by a Quanta 200 (FEI, Eindhoven, the Netherlands) or by CarryScope JCM-5700 (JEOL, USA) scanning electron microscope.

Morphometric measurements were made either from the calibrated digital light microscope (LM) images using Leica Application Suite v. 3.7 software (Leica Microsystems Ltd., Switzerland) or were calculated from scanning electron micrographs. Dimensions are given as the mean \pm standard deviation. SEM photographs were presented on a black background using Adobe Photoshop CS2, v. 9.0.2 (Adobe Systems, San Jose, CA, USA). The material collected during this survey is deposited in the regional collection of microalgae at Marine Science Centre, University of Basrah, Iraq.

\section{Results}

Species identification of small bloom-forming Iraqi Peridiniopsis was based on observations of its morphological characters using light, epifluorescence, and scanning electron microscopy. Both alive and preserved cells from field samples were examined. Based on the main diagnostic features of the genus Peridiniopsis (Bourrelly
1968; Popovský and Pfiester 1990) including cell shape and dimensions, thecal surface ornamentation, and the size, shape, and position of the anterior intercalary plate, the small Peridiniopsis taxon from the Shatt Al-Arab River was assigned to $P$. minima Zhang, Liu \& $\mathrm{Hu}$, a species originally described recently from the Jiulongjiang River, China (Zhang et al. 2014).

\section{Systematics}

Class DINOPHYCEAE West \& Fritch, 1927

Order PERIDINIALES Haeckel, 1894

Family PERIDINIACEAE Ehrenberg, 1830

Genus Peridiniopsis Lemmermann, 1904

Peridiniopsis minima Zhang, Liu \& Hu, 2014

Figs. 2 and 3

\section{Description}

Cells were oval to almost rhombic in shape and slightly dorso-ventrally compressed, with nearly equal in size conical epitheca and smoothly round hypotheca (Figs. 2a; 3a, c, e). Cells measured 13.5-19.04 $\mu \mathrm{m}$ in length (mean $16.27 \pm 1.66, n=14$ ), $12.8-17.9 \mu \mathrm{m}$ in width (mean 15.05 $\pm 1.65, n=11$ ), and $12.3-15.3 \mu \mathrm{m}$ in depth (mean 13.71 $\pm 1.04, n=7$ ), with length to width ratio of $1.01-1.1$. The cingulum was nearly equatorial, excavated, and descending with a displacement of about half of its own width. The sulcus was excavated and extended from the cingulum to the antapex (Figs. 2c, e, f and 3a-c, h). Numerous small, golden-brown disc-shaped chloroplasts were peripherally arranged (Fig. 2a-c). Relatively large round dinokaryon was centrally located. Endosymbiont nucleus was present (Fig. 2b-d). Distinct red eyespot was located in the sulcal area (Fig. 2a, b). No pyrenoid was observed.

The plate tabulation was Po, X, 3', 1a, 6", 5c, 5 s, 5' ', 2 '"' '. The epitheca consisted of twelve symmetrically arranged plates. The apical pore plate (Po) was elongate and possessed slit-like and slightly curved apical pore. The canal plate $(\mathrm{X})$ was small, rectangular, and situated between Po, 1', 2' and $3^{\prime}$ on the ventral side of the cell (Figs. 2i, $j$ and 3f). The Po plate was encircled by three apical plates $\left(1^{\prime}-3^{\prime}\right)$, of which plate $1^{\prime}$ was in contact with the sulcus and connected to the apical pore plate by the canal plate (Figs. $2 \mathrm{~h}-\mathrm{j}$ and $3 \mathrm{a}, \mathrm{e}$ ). The first apical plate $\left(1^{\prime}\right)$ was large, rhombic; the plates 2 ' and 3 ' were large, irregularly six-sided, and mainly located dorsally. 


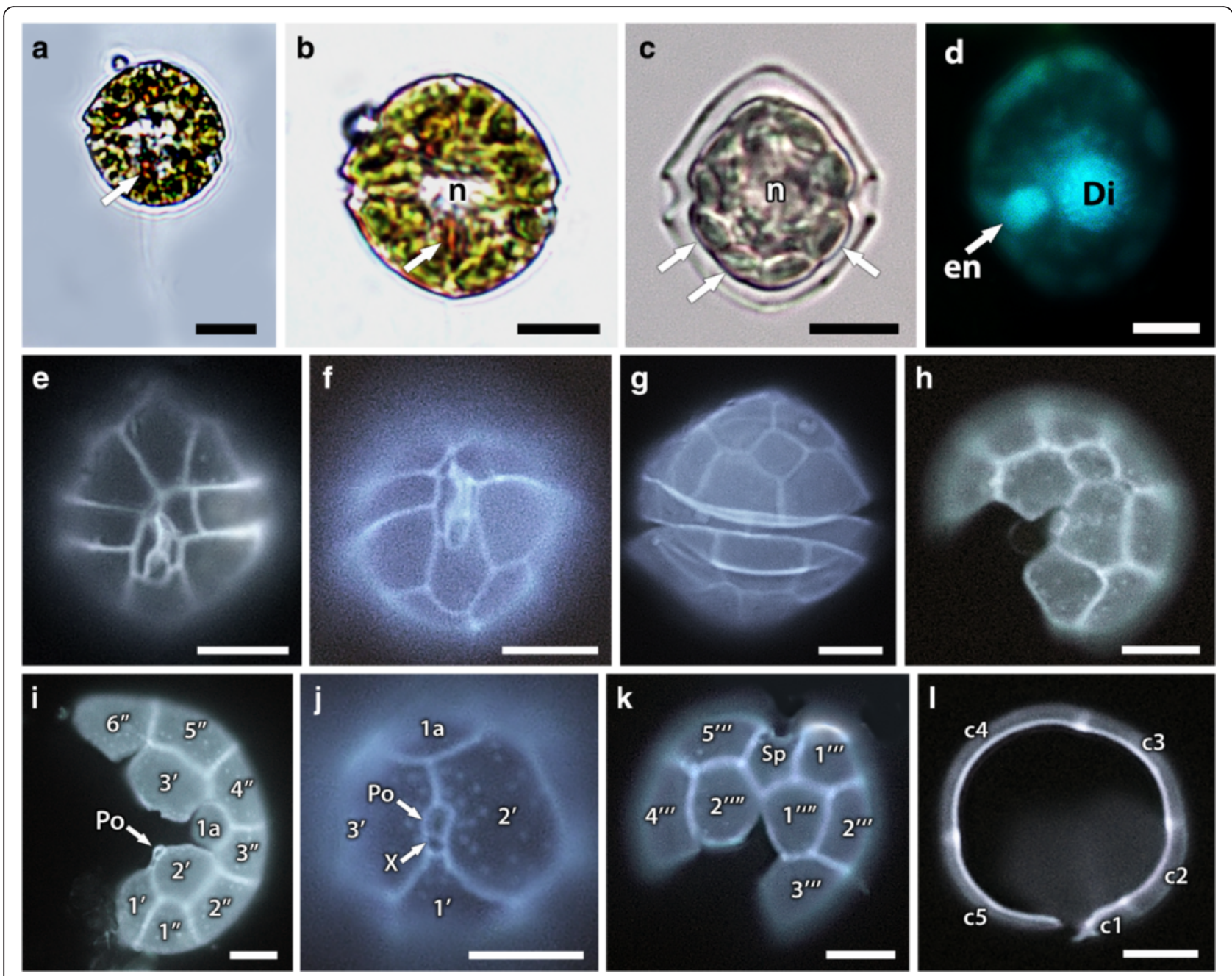

Fig. 2 Light micrographs of Peridiniopsis minima from Iraq. (a, b) cell from freshly collected sample in ventral view showing general appearance, nucleus (n) and chloroplasts arrangement, arrows point to eyespot; (c) preserved cell showing central nucleus (n) and peripherally arranged chloroplasts (arrows); (d) DAPI stained cell showing dinokaryotic (Di) and endosymbiont (en, arrow) nuclei; (e-g) calcofluor stained cells in ventral $(\mathbf{e}, \mathbf{f})$ and dorsal $(\mathbf{g})$ view showing the thecal plate tabulation; (h, i) split calcofluor stained epitheca in apical view showing the epithecal plate pattern; (j) detail of the apical pore complex and surrounded apical plates; (k) split calcofluor stained hypotheca in antapical view showing the hypothecal plate pattern; (I) cingular plate pattern. Scale bars: 5 um

The single anterior intercalary plate (1a) was relatively small, rhombic, and located symmetricaly on dorsal cell side between 2', 3', 3' 'and 4' epithecal plates (Figs. 2g$\mathrm{i}$ and $3 \mathrm{~b}, \mathrm{e})$. There were six precingular plates, among them the plates $1^{\prime \prime}, 2$ ' ' and $5^{\prime \prime}$ 'were four-sided, whereas the plates $3^{\prime \prime}, 4{ }^{\prime \prime}$ and $6^{\prime \prime}$ were pentagonal.

The hypotheca possessed rather symmetrically arranged five postcingular $\left(1^{\prime \prime \prime}-5{ }^{\prime \prime \prime}\right)$ and two antapical $\left(1^{\prime \prime \prime}\right.$ and $\left.2^{\prime \prime \prime \prime}\right)$ plates. The first $\left(1^{\prime \prime \prime}\right)$ and fifth $\left(5^{\prime \prime \prime}\right)$ postcingular plates were large and covered most of the ventral side of the hypotheca, whereas the 2 "' -4 "' plates together with the two antapical plates cover the dorsal side of the hypotheca (Figs. 2f, $\mathrm{k}$ and $3 \mathrm{a}, \mathrm{b}$ ).

The cingulum consisted of five unequal plates (c1c5), among them the first cingular plate was smallest in the cingular series (Figs. $2 \mathrm{l}$ and 3a). In the sulcus, which consisted of five plates, the small anterior sulcal plate $(\mathrm{Sa})$ is contiguous with the first cingular plate at the left end of the cingulum and touched the plates $1^{\prime}, 6^{\prime \prime}$ and $c 6$. The large right sulcal plate $(\mathrm{Sd})$ was relatively narrow, elongate, and had a thin internal sulcal list (sl) on its left margin. The left sulcal plate (Ss) was elongate and extended along the right side of the first cingular plate $\mathrm{c} 1$ and the first postcingular plate $1^{\prime \prime \prime}$. The median sulcal plate $(\mathrm{Sm})$ was small and located between the lower parts of Sd and Ss. The posterior sulcal plate (Sp) was the largest of the sulcal series, wider toward the posterior, and elongated to the antapex between the first and fifth postcingular plates (Figs. 2e, f and $3 \mathrm{~h}, \mathrm{i}$ ). 

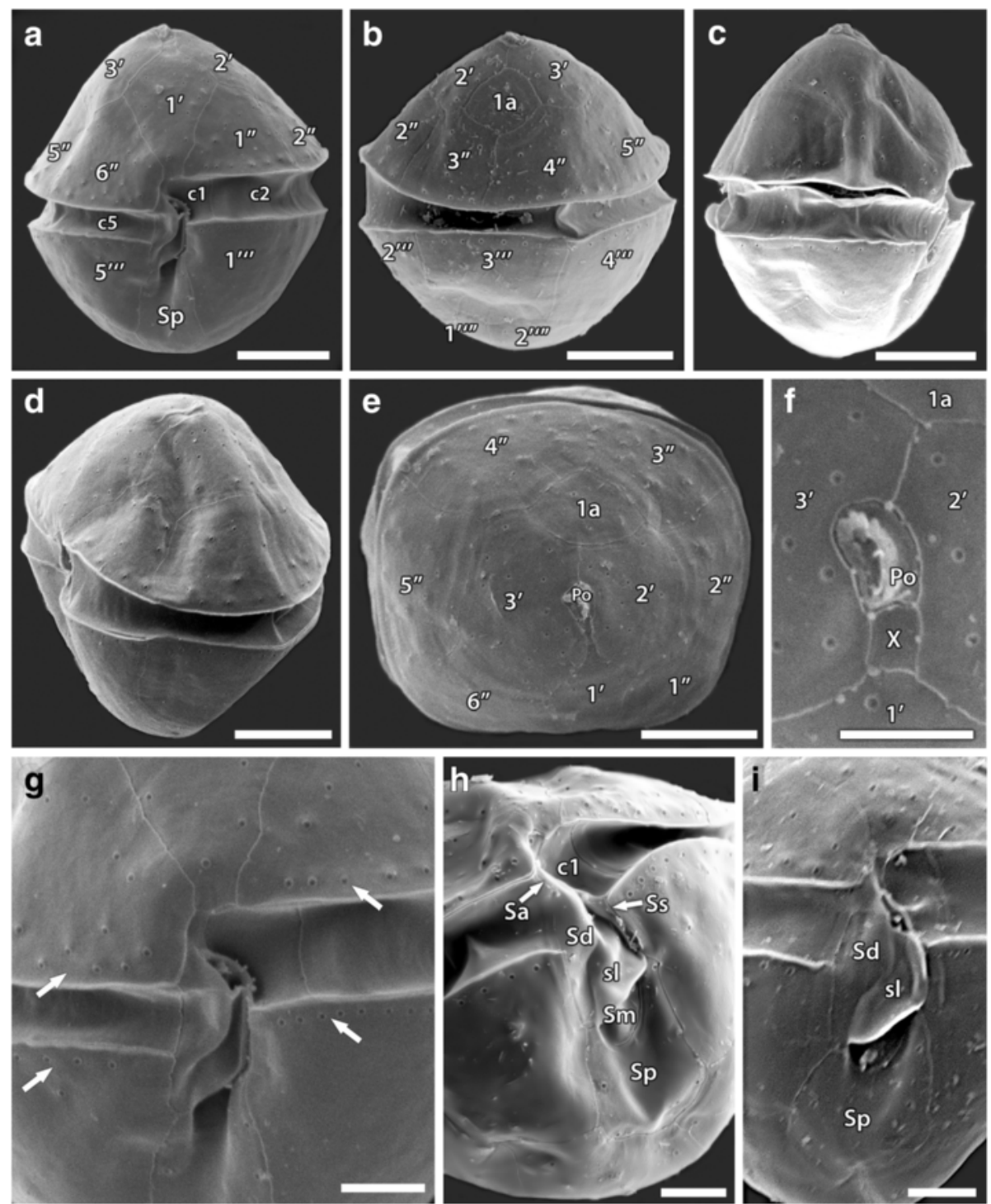

Fig. 3 Scanning electron micrographs of Peridiniopsis minima from Iraq. (a) ventral view; (b) dorsal view; (c) oblique right lateral view; (d) oblique left lateral view; (e) apical view; (f) detail of the apical view showing the apical pore complex with surrounded apical plates; ( $\mathbf{g}$-i) detail of theca in ventral view showing marginal rows of densely lying pores (G, arrows) and plate pattern of the sulcal series (h, i). Scale bars: A-E, $5 \mu \mathrm{m}$; F-l, $2 \mu \mathrm{m}$

The thecal surface was smooth with small rimmed pores $(0.15-0.16 \mu \mathrm{m}$ in diameter) scattered sparsely over the plates (Figs. $2 \mathrm{~h}, \mathrm{j}$ and $3 \mathrm{e}-\mathrm{g}$ ). Densely lying pores formed distinct marginal rows along the upper and lower edges of the pre- and postcingular plates bordering the cingulum (Fig. 3g). The cingular and sulcal plates were lacking pores, except for the Sp plate (Fig. 3h, i).

\section{Known distribution and occurrence}

Peridiniopsis minima has been originally described from the freshwater phytoplankton assemblage in the Jiulongjiang River, Fujian Province of China as bloom-forming species (Zhang et al. 2014). Similarly, in the Shatt AlArab River system this species represented a major proportion of the overall phytoplankton assemblage at sites 1 and 2 during November and December 2009, and to a lesser extent at site 3 in April 2010. The occurrence of $P$. minima was recorded along the Shatt $\mathrm{Al}$-Arab River at temperatures ranging from $19.3{ }^{\circ} \mathrm{C}$ to $23.9{ }^{\circ} \mathrm{C}$ and salinity range from 2 to 7.2 (Table 1 ).

\section{Discussion}

The genus Peridiniopsis was originally described by Lemmermann in 1904 and later was revised by the addition of species formerly assigned to Glenodinium Ehrenberg and Peridinium Ehrenberg (Bourrelly 1968). The current classification of Peridiniopsis holds together species with varying numbers of plates in epithecal and 
cingular Kofoidian series, and restricted to species with no or one anterior intercalary plate (Bourrelly 1968). The plate formula of the genus Peridiniopsis is defined as 3-5', 0-1a, 6-8", 5-6c, 3-5 s, 5'"', 2'"' (Bourrelly 1968, 1985; Popovský and Pfiester 1990). In the present study, based on analysis of thecal plate pattern, the small peridinioid dinoflagellate from the Shatt Al-Arab River, Iraq was attributed to the genus Peridiniopsis.

Except for its size, the Peridiniopsis species that we collected in Iraq agreed well with the original description of P. minima (Zhang et al. 2014) in respect of cell shape, cytoplasm content, and thecal arrangement including the characteristic shape and position of small anterior intercalary plate (Table 2). The cell size of the Iraqi specimens was slightly larger $(13.5-19.04 \mu \mathrm{m}$ in length and $12.8-17.9 \mu \mathrm{m}$ in width) than the ones of the originally described $P$. minima $(8-15 \mu \mathrm{m}$ in length, 6$12 \mu \mathrm{m}$ in width; Zhang et al. 2014) but their size ranges overlap in length and can be considered as intraspecific variability.

The original description of P. minima was based on LM observations without details of the thecal surface structure, and a molecular characterization of ribosomal genes and ITS regions (Zhang et al. 2014). Our new observations of cells from Iraq add previously unreported details to the description of this species regarding the
APC and sulcus structure and the thecal surface ornamentation. Based on specimens examined by SEM, the slit-like shape of the apical pore, the thecal pores size and its arrangement were documented. Additionally, the presence of a fifth small median sulcal plate was confirmed in the composition of the sulcal area as well as the small internal sulcal list was revealed in the right sulcal plate. In order to confirm its identity with $P$. minima and evaluate its phylogenetic position among other freshwater and marine dinoflagellates, we made several attempts to amplify DNA and get a sequence of this species during this study. However, all stayed unsuccessful and only contaminant (fungi) sequences could be amplified from fixed samples. Hence, obtaining a sequence of this species remains to be done and further analyses will be carried out in the future.

The present work brings new data on the occurrence of the bloom-forming $P$. minima for the first time in the waters of Shatt Al-Arab River, which is considered an important contribution to the aquatic flora of Iraq. Moreover, our observations of freshwater P. minima in brackish waters of the Shatt Al-Arab River system in appreciable concentrations extend the known range of salinity tolerance for this species. From an ecological point of view, only a few Peridiniopsis species have been described to cope with salty waters. Actually, species in the

Table 2 Morphological comparison of the brackish water Peridiniopsis species

\begin{tabular}{|c|c|c|c|c|c|c|}
\hline & P. minima ${ }^{a}$ & P. minima ${ }^{b}$ & P. salina & $\begin{array}{l}\text { P. cristata var. } \\
\text { cristata }^{\text {def, f,g }}\end{array}$ & $\begin{array}{l}\text { P. cristata var. } \\
\text { boliviensish }\end{array}$ & $\begin{array}{l}\text { P. cristata var. } \\
\text { tubulifera }^{\mathrm{h}}\end{array}$ \\
\hline Cell shape & oval to rhombic & $\begin{array}{l}\text { pentagonal to } \\
\text { rhombic }\end{array}$ & oval to spherical & pyriform & ovoid to subspherical & pyriform \\
\hline Length $(\mu \mathrm{m})$ & $13.5-19.04$ & $8-15$ & $9.1-14.5$ & (37) 43-61 & $32-40$ & (27) $30-40$ \\
\hline Width $(\mu \mathrm{m})$ & $12.8-17.9$ & $6-12$ & $7.3-12.9$ & $29-41$ & $30-38$ & $26-32$ \\
\hline $\begin{array}{l}\text { Theca } \\
\text { ornamentation }\end{array}$ & smooth & smooth & smooth & $\begin{array}{l}\text { verrucose to } \\
\text { reticulate }\end{array}$ & finely reticulated & smooth \\
\hline Epitheca & $\begin{array}{l}\text { broadly conical, } \\
\text { equal to hypotheca }\end{array}$ & $\begin{array}{l}\text { broadly conical, } \\
\text { equal to hypotheca }\end{array}$ & $\begin{array}{l}\text { broadly conical, } \\
\text { equal to hypotheca }\end{array}$ & $\begin{array}{l}\text { helmet-shaped, } \\
\text { higher than } \\
\text { hypotheca }\end{array}$ & $\begin{array}{l}\text { broadly conical, equal } \\
\text { to hypotheca }\end{array}$ & $\begin{array}{l}\text { helmet-shaped, } \\
\text { higher than } \\
\text { hypotheca }\end{array}$ \\
\hline $\begin{array}{l}\text { Plate } \\
\text { tabulation }\end{array}$ & $\begin{array}{l}\text { Po, } X, 3^{\prime}, 1 \mathrm{a}, 6 ", 5 \mathrm{c} \\
5 \mathrm{~s}, 5^{\prime \prime \prime}, 2^{\prime \prime \prime \prime}\end{array}$ & $\begin{array}{l}\mathrm{Po}, \mathrm{X}, 3^{\prime}, 1 \mathrm{a}, 66^{\prime \prime}, 5 \mathrm{c}, \\
4 \mathrm{~s} ?, 5^{\prime \prime \prime}, 2^{\prime \prime \prime \prime}\end{array}$ & $\begin{array}{l}\mathrm{Po}, X_{1} 4^{\prime}, 1 \mathrm{a}, 66^{\prime \prime}, 6 \mathrm{c}, \\
5 \mathrm{~s}, 5^{\prime \prime \prime}, 2^{\prime \prime \prime \prime}\end{array}$ & $\begin{array}{l}\text { Po, X?, 3', 1a, 6", 6c, } \\
4-5 \text { s?, 5"', 2"'"' }\end{array}$ & $\begin{array}{l}\text { Po, X?, 3', 1a, 6", ?c, } \\
\text { ?s, 5"', 2"'!' }\end{array}$ & $\begin{array}{l}\text { Po, X, 3', 1a, 6", 6c, } \\
5 s, 5^{\prime \prime \prime}, 2^{\prime \prime \prime \prime}\end{array}$ \\
\hline $\begin{array}{l}\text { Intercalary } \\
\text { plate }\end{array}$ & small, rhombic & small, rhombic & small, rhombic & large, hexagonal & large, hexagonal & large, hexagonal \\
\hline $\begin{array}{l}\text { Intercalary } \\
\text { plate location }\end{array}$ & $\begin{array}{l}\text { dorsally between } \\
2^{\prime}, 3^{\prime}, 3^{\prime \prime} \text { and } 4^{\prime \prime}\end{array}$ & $\begin{array}{l}\text { dorsally between } \\
\text { 2', 3', 3"and 4" }\end{array}$ & $\begin{array}{l}\text { laterally between } \\
2^{\prime}, 3^{\prime}, 2 \text { "and 3" }\end{array}$ & $\begin{array}{l}\text { dorsally between 2', } \\
3^{\prime}, 2^{\prime \prime}, 3^{\prime \prime}, 4^{\prime \prime} \text { and 5" }\end{array}$ & $\begin{array}{l}\text { dorsally between 2', } \\
3^{\prime}, 2^{\prime \prime}, 3^{\prime \prime}, 4^{\prime \prime} \text { and 5" }\end{array}$ & $\begin{array}{l}\text { dorsally between 2', } \\
3^{\prime}, 2^{\prime \prime}, 3^{\prime \prime}, 4^{\prime \prime} \text { and 5" }\end{array}$ \\
\hline Apical spine & no & no & no & $\begin{array}{l}\text { small dorsal } \\
\text { membranous crest }\end{array}$ & $\begin{array}{l}\text { absent or tiny dorsal } \\
\text { membranous crest }\end{array}$ & no \\
\hline $\begin{array}{l}\text { Antapical } \\
\text { spine }\end{array}$ & no & no & no & $\begin{array}{l}\text { membranous crest- } \\
\text { shaped extension }\end{array}$ & $\begin{array}{l}\text { membranous crest- } \\
\text { shaped extension }\end{array}$ & no \\
\hline Eyespot & yes & yes & no & no & no & yes \\
\hline Endosymbiont & yes & yes & $?$ & $?$ & $?$ & $?$ \\
\hline $\begin{array}{l}\text { Habitat } \\
\text { (salinity range) }\end{array}$ & $\begin{array}{l}\text { brackish waters } \\
(2-7.2)\end{array}$ & fresh water rivers & $\begin{array}{l}\text { brackish waters } \\
(2.2-16.2)\end{array}$ & $\begin{array}{l}\text { brackish waters } \\
\left(4.3^{5}-5.7^{6} ; 3-7^{7}\right)\end{array}$ & brackish waters (7.5) & brackish waters (5.7) \\
\hline
\end{tabular}

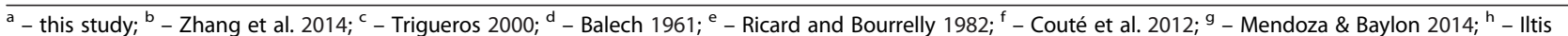
and Couté 1984; ? - no information 
genus Peridiniopsis are generally typical of freshwater environments (Bourrelly 1985) and absent from salty waters. To date, two species were reported from brackish waters so far, Peridiniopsis salina Trigueros (Trigueros 2000) and Peridiniopsis cristata (Balech) Bourrelly (Balech 1961; Couté et al. 2012; Mendoza and Baylon 2014). A comparison between Iraqi $P$. minima and other brackish water Peridiniopsis species is made in Table 2 . In the case of $P$. salina, this small species from the Atlantic Ocean reached highest concentrations at salinities between 2.2 and 16.2 (Trigueros 2000), but it might be related to another heterotrophic genus of pfiesteriacean dinoflagellates (Moestrup, pers. comm.). The three different varieties of $P$. cristata are, however, typical of slightly brackish waters of Clipperton lagoon in the eastern Pacific Ocean (Couté et al. 2012), but also of saline lake in Bolivia (Iltis and Couté 1984) and of saline Encantada lagoon in Peru (Mendoza and Baylon 2014). $P$. cristata can tolerate salinities up to 7.5 , which is remarkably similar with our observations on $P$. minima during this study. Among brackish water Peridiniopsis taxa, P. minima is clearly distinguishable from smallsized $P$. salina by thecal arrangement of the epitheca, and from $P$. cristata by smaller size, shape, and size of the anterior intercalary plate (in case of $P$. cristata var. tubulifera Couté, Perrette \& Chomérat), and by the absence of apical and antapical crests and thecal ornamentation (in case of $P$. cristata var. cristata and P. cristata var. boliviensis Iltis \& Couté) (Table 2).

\section{Conclusion}

The outbreaks of dinoflagellates in different aquatic environments signify a real ecological threat to these systems. Blooming of these microorganisms has been linked to anthropogenic pollution, human-mediated dispersal of species and climate changes (e.g., Hallegraeff 1993; Anderson et al. 2002). The discovery of bloomforming dinoflagellate species in Shatt Al-Arab River system makes evident the necessity of comprehensive monitoring program of phytoplankton as microalgal blooms could be a major problem for aquatic biota and for human living in Basrah city because the river serves as drinking water supply. Therefore, more studies on the ecology and physiology of this species and other dinoflagellates are required to grasp processes that lead to their outgrowth and to decide an appropriate management plan for the river ecosystem in case such event recurs.

\footnotetext{
Abbreviations

$1-2^{\prime \prime \prime \prime}$, antapical plate series; $1-3^{\prime}$, apical plate series; $1-5^{\prime \prime \prime}$, postcingular plate series; $1-6^{\prime \prime}$, precingular plate series; $1 \mathrm{a}$, anterior intercalary plate; $\mathrm{c} 1-\mathrm{c} 5$, cingular plate series; Po, apical pore plate; Sa, anterior sulcal plate; Sd, right sulcal plate; Sl, sulcal list; Sm, median sulcal plate; Sp, posterior sulcal plate; Ss, left sulcal plate; $X$, canal plate
}

\section{Acknowledgments}

The authors wish to thank the Marine Science Centre, University of Basrah, Iraq for the financial support of the sampling program and use of their facilities. Thanks to Mr. Aqil Abdul Saheb (Department of Biology, Marine Science Centre, University of Basrah, Iraq) for his help in sampling. We also acknowledge Ms. Ahlam S. Al-Kadi and Mr. Mohammed T. Rajab (Nanoscopy Science Center, Faculty of Science, Kuwait University, Kuwait City, Kuwait) for their skillful technical assistance with SEM. We greatly appreciate the two anonymous reviewers for their helpful comments and suggestions, and the MBDR editorial team, especially Dr. John Raven, for their kind help.

\section{Authors' contributions}

HAH: conceived of the study, carried out the sampling design and field work, participated in the acquisition of biological data and species identification, measured the environmental parameters and helped to draft the manuscript. MS: participated in the identification of the species and LM and SEM examinations, processed the illustrations and drafted the manuscript. NC: participated in the identification of the species and SEM examinations, supporting literatures and contributed to draft the manuscript. All authors read and approved the final manuscript.

\section{Competing interests}

The authors are declaring that there are no competing interests.

\section{Author details}

${ }^{1}$ Department of Environmental Marine Chemistry, Marine Science Centre, University of Basrah, Basrah, Iraq. ${ }^{2}$ Environment and Life Sciences Research Center, Kuwait Institute for Scientific Research, P.O. BOX 1638, 22017 Salmiya, Kuwait. ${ }^{3}$ IFREMER, LER BO, Station de Biologie Marine, Place de la Croix, F-29900 Concarneau, France.

Received: 19 May 2016 Accepted: 3 June 2016

Published online: 11 July 2016

\section{References}

Al-Handal AY. New additions to the algal flora of Iraq. J Univ Kuwait. 1989;16:97104.

Al-Zubaidi AJM, Abdullah DS, Houriabi KK, Fawzi M. Abundance and distribution of phytoplankton in some southern Iraqi waters. Marsh Bull. 2006;1(1):59-73.

Anderson DM, Glibert PM, Burkholder JM. Harmful algal blooms and eutrophication: Nutrient sources, composition, and consequences. Estuaries. 2002;25:704-26. doi:10.1007/BF02804901.

Balech E. Glenodinium cristatum, sp. nov. (Dinoflagellata). Neotropica. 1961;7(23): 47-51.

Bourrelly P. Notes sur les Peridiniens d'eau douce. Protistologica. 1968;4:5-14.

Bourrelly P. Les Algues d'Eau Douce. Initiation à la Systématique. Tome III: Les Algues Bleues et Rouges. Les Eugléniens, Péridiniens et Cryptomonadines. 2nd ed. Paris: N Boubée; 1985.

Couté A, Perrette C, Chomérat N. Three Dinophyceae from Clipperton Island lagoon (eastern Pacific Ocean), including a description of Peridiniopsis cristata var. tubulifera var. nov. Bot Mar. 2012;55:59-71. doi:10.1515/bot-2011-121.

Fritz L, Triemer RE. A rapid simple technique utilizing calcofluor white M2R for the visualization of dinoflagellate thecal plates. J Phycol. 1985;21:662-4. doi:10.1111/j.0022-3646.1985.00662.x.

Hallegraeff GM. A review of harmful algal blooms and their apparent global increase. Phycologia. 1993;32:79-99. doi:10.2216/i0031-8884-32-2-79.1.

Hansen G, Flaim G. Dinoflagellates of the Trentino Province, Italy. J Limnol. 2007; 66:117-26. doi:10.4081/jlimnol.2007.107.

Huq MF, Al-Saadi HA. et al. Hameed HA Phytoplankton ecology of Shatt al-Arab River at Basrah, Iraq. Verh Int Verein Limnol. 1978;20:1552-6.

Iltis A, Couté A. Peridiniales (Algae, Pyrrhophyta) de Bolivie. Rev Hydrobiol Trop. 1984;17:279-86.

Kell V, Saad MAH. Untersuchungen über das Phytoplankton und einige Umweltparameter des Shatt Al-Arab, Irak. Int Revue Ges Hydrobiol. 1975;60: 409-21.

Ki J-S, Han M-S. Sequence-based diagnostics and phylogenetic approach of uncultured freshwater dinoflagellate Peridinium (Dinophyceae) species, based on single-cell sequencing of rDNA. J Appl Phycol. 2005;17:147-53. doi:10.1007/s10811-005-7211-y. 
Mac Donagh NE, Casco MA, Claps MC. Colonization of a neotropical reservoir (Córdoba, Argentina) by Ceratium hirundinella (O.F. Müller) Bergh. Ann Limnol. 2005:41:291-9. doi:10.1051/limn/2005020.

Maulood BK, Hadi RAM, Saadalla HAA, Kassim TI, Al-Lami AA. Checklist of the algae in Iraq. Marina Mesopotamica 1993;1(suppl):1-128.

Maulood BK, Hassan FM, Al-Lami AA, Toma JJ, Ismail AM. Checklist of Algal Flora in Iraq. Iraq: Ministry of Environment; 2013.

Mendoza L, Baylon M. Primer reporte de Peridiniopsis cristata (Balech) Bourrelly en una laguna salobre de la región costera del Perú. In: IV Congreso de Ciencias del Mar (CONCIMAR), Junio de 2014, Lima, Perú; 2014, Conference paper https:/www.researchgate.net/publication/264417403_Primer_reporte_de_ Peridiniopsis_cristata_Balech_Bourrelly_en_una_laguna_salobre_de_la_ region_costera_del_Peru

Popovský J, Pfiester LA. Dinophyceae (Dinoflagellida). In: Ettl H, Gerloff J, Heynig H, Mollenhauer D, editors. Süßwasserflora von Mitteleuropa. Band 6. Jena: Gustav Fischer Verlag; 1990. p. 1-272.

Ricard M, Bourrelly P. Quelques alques microscopiques du lagon de l'atoll de Clipperton (Pacifique Tropical Nord). Cryptog Algol. 1982;3:25-31.

Salman JM, Jawad HJ, Nassar AJ, Hassan FM. A study of phytoplankton communities and related environmental factors in Euphrates River (between two cities: Al-Musayyab and Hindiya), Iraq. J Envir Protection. 2013;4:1071-9. doi:10.4236/jep.2013.410123.

Takano Y, Hansen G, Fujita D, Horiguchi T. Serial replacement of diatom endosymbionts in two freshwater dinoflagellates, Peridiniopsis spp. (Peridiniales, Dinophyceae). Phycologia. 2008;47:41-53. doi:10.2216/07-36.1.

Triqueros JM. Peridiniopsis salina (Peridiniales, Dinophyceae), a new species of brackish dinoflagellate from Urdaibai estuary, North Spain. Phycologia. 2000; 39:126-33. doi:10.2216/i0031-8884-39-2-126.1.

Zhang Q, Liu G, Hu Z. Description of a new freshwater bloom-forming dinoflagellate with a diatom endosymbiont, Peridiniopsis minima sp. nov. (Peridiniales, Dinophyceae) from China. Algol Stud. 2014;145/146:119-33; doi: 10.1127/1864-1318/2014/0159

\section{Submit your next manuscript to BioMed Central and we will help you at every step:}

- We accept pre-submission inquiries

- Our selector tool helps you to find the most relevant journal

- We provide round the clock customer support

- Convenient online submission

- Thorough peer review

- Inclusion in PubMed and all major indexing services

- Maximum visibility for your research

Submit your manuscript at www.biomedcentral.com/submit 